\title{
E 205
}

\section{$\mathrm{A}$ 型肝炎ワクチン 2 回接種後の抗体陽性率}

\section{○名倉誠朗＼cjkstart林剛司 菅原陽一 \\ 日立健康管理セン夕}

目的 海外出張前に実施した A 型肝炎ワクチン 2 回接種の有効性を明らかにすること。 対象 1996 年 5 月から 2001 年 8 月 31 日までに A 型肝炎ワクチン接種を目的に当センタを受診し、 抗体検査にて陰性であった受診者996名にワクチン接種を施行した。接種した996名の従業員のうち、 2 回接種後に抗体検査を施行した従業員 75 名を対象とした。年齢 25 歳一58 歳（平均 40.4 歳）、男性 69 名、女性 6 名であった。

方法 任国前に 2 回接種のみで渡航した従業員のうち、帰国時健診時において再度海外出張の可能性 がある者、及び 3 回目接種目的でセンタを受診した者について、抗体の有無を調査した。A 型肝炎ワ クチンは乾燥組織培養不活化ワクチン(生研) $0.5 \mu \mathrm{g}$ を使用し、接種方法は三角筋筋肉内注射とした。抗 体検査試薬はアキシム HA・ダイナパックを使用し、EIA 法にて測定し $20 \mathrm{mIU} / \mathrm{ml}$ 以上を陽性とした。 抗体陽性群と抗体陰性群において、接種間隔、抗体検査までの期間、性別、重篤な副反応の有無、A 型肝炎感染者数を比較検討した。統計は student-t test、 $\chi$ 二乗検定を用い、有意水準は $5 \%$ とした。 結果 75 名のうち、抗体陽性者は 44 人、陰性者は 31 人で抗体陽性率は $58.7 \%$ あった。 両群間での接種間隔、抗体検查までの期間、性別、重篤な副反応の有無、A 型肝炎感染者数の比較を 表 1 に示した。いずれも、両群間で有意差は認めなかった。

表 1

\begin{tabular}{|l|l|l|l|l|l|}
\hline & 抗体陽性群 & 抗体陰性群 & & 抗体陽性群 & 抗体陰性群 \\
\hline 抗体接種間隔 & 平均 35.9 日 & 平均 40.9 日 & 性別（男 / 女） & 39 人 / 5 人 & 30 人 / 1 人 \\
\hline 抗体検査期間 & 平均 94.9 週 & 平均 77.7 週 & 副反応 - 感染者 & 0 人 & 0 人 \\
\hline
\end{tabular}

考察 当センタでは、管轄從業員の WHO が指定する A 型肝炎流行地域への海外出張者に対し、出張 前にワクチン接種を施行している。日本で使用されている乾燥組織培養不活化ワクチンは、 3 回の接種 が推奖されている。用法は、2-4 週間隔で 2 回、さらに 1 回目接種日から 24 週を経過した後に 3 回 目の追加接種を行う。しかし、出張決定日から出発日まで数週間しかなく、2 回接種のみでの渡航を行 っているのが現状である。国内での報告では 2 回のみの接種でも、その 4 週後の抗体陽性率は $100 \%$ であり、さらに 24 週後に測定しても $100 \%$ の陽性率の報告がされている。今回の調查結果で 2 回接種 では、58.7\%の陽性率しか獲得できていないことが明らかになった。原因として 2 回の接種間隔、2 回接種後の抗体検査までの期間、性別を調査したがいずれも有意差は認めず、これらは低い陽性率の 原因とは考えにくい。我々の調查では海外出張期間の問題があり、抗体検査までの期間が長期に及ん でいるため、出張時は抗体獲得していても抗体検查時には抗体価が低下していた可能性は考えられる。 しかし、2 回接種のみでは、出張時も抗体獲得できていなかった可能性を否定できない。

結語 $1 、 2$ 回接種では海外出張時に抗体獲得できていない可能性がある。

2、抗体獲得および長期間の抗体獲得持続のためには 3 回接種がすすめられる。 